\title{
Eman ta Zabal Zazu Garapen Iraunkorrerako 14. Helburuaren alde: itsaspeko bizitza... eta bizia
}

\author{
(Eman ta Zabal Zazu for the good of sustainable development \\ goal 14: life bellow water)
}

Ibon Cancio*

CBET Research Group, Dept. Zoology \& Animal Cell Biology;

Faculty of Science \& Technology and

Research Centre for Experimental Marine Biology and Biotechnology (PiE-UPV/EHU)

\begin{abstract}
LABURPENA: 2015ean, Nazio Batuen Erakundeak Garapen Iraunkorrerako 17 helburu ezarri zituen, planeta osorako, hots, etorkizun jasangarriago bat lortzeko bide-orria. Helburuak 2030. urtera arteko plan gauzagarri bat iradokitzeko asmoarekin jaio ziren, planeta eta espezie gisa gure aurrean ditugun erronka guztiei erantzuteko: 2030erako Agenda Unibertsala. Haien artean, 14. helburua, itsaspeko bizitzarena, zeharkakoenetako bat da, itsasoek gure planetako biziaren garapenerako espazioaren \% 99 osatzen duten heinean. Bizia itsasoan sortu zen, eta bertan topatu zuen ostatua eta garatzeko zein eboluzionatzeko bidea. Eta, «hauts hartatikan uste gabean noizbait ginaden gu ernai» abestiaren hitzak nolabait gaiari ekarriz, itsasotik noizbait lehorreratuko ziren izaki bizidun batzuk. Gure giza fluidoetan eta odoleko gatz-kontzentrazioan gelditzen da kresal haren arrastoa. Ozeanoak dira planetaren ezaugarri nabarmenena: Lurraren ia hiru laurdenak estaltzen dituzte. Ozeanoak funtsezkoak dira Lurraren iraupenerako, hots, Lurraren arnas sistema dira. Itsas fitoplanktonak bizitzarako oxigenoaren \% 50 sortzen du, eta karbono dioxidoaren \% 30 xurgatzen. Ozeanoek klima eta tenperatura erregulatzen dituzte, eta planeta bizia jasotzeko gai bihurtzen dute era askotako bizimoduetarako. Hala ere, 14. helburuaren xedea lortzeko asmotan, Ozeanoen Osasun Indizeak eta Garapen Iraunkorrerako Txostenak iradoki dute ez goazela bide onetik. Horrela, Nazio Batuen erakundeak «Garapen Iraunkorrerako Zientzia Ozeanikoen Hamarkada» izendatu du 2021-2030eko tartea. Horretan, garrantzitsuak izango dira itsas ikerketako azpiegituretan - besteak beste, Plentziako Itsas Estazioan (PiE-UPV/EHUn) - ikertzen diharduten zientzialari, teknikari eta ikasleak.
\end{abstract}

HITZ GAKOAK: ozeanoak, iraunkortasuna, osasuna, baliabideak, ikerketa.

\begin{abstract}
In 2015, the United Nations established 17 Sustainable Development Goals (SDG), launching a roadmap for a more sustainable future of our planet. The objectives were born aimed at suggesting a feasible plan until 2030, which would respond to all the challenges we face as a planet and species: the Universal Agenda for 2030. Among them, SDG 14, that of life bellow water, can be considered one of the most transversal, since the oceans represent $99 \%$ of the space where life thrives in this planet. Life was initiated at sea, where living organisms found accommodation and a place to develop and evolve. From there some living beings would disembark on land and «and once upon a time from such dust unwillingly, we were born», bringing somehow the words of the song to our subject. Like us, the trace of this salt water remains in our fluids and in the solute concentration in our blood. The oceans are the main feature of the planet, as they cover almost three quarters of the Earth and are fundamental to its survival. The seas are the Earth's respiratory system: marine phytoplankton produces 50\% of the oxygen for life and absorbs 30\% of the world's carbon dioxide. The oceans regulate climate and temperature, making the planet habitable for very diverse forms of life. However, the analyses carried out on SDG 14, the Ocean Health Index and the Sustainable Development Report, suggest that we are not addressing its objectives very well in order to achieve the goal for 2030. More knowledge is needs and therefore the United Nations has declared that the decade 202I-2030 will be the «Decade of Ocean Sciences for Sustainable Development». The scientists, technicians and students that carry out research in marine research infrastructures such as the Plentzia Marine Station (PiE-UPV/EHU) will be relevant for the next decade.
\end{abstract}

KEYWORDS: oceans, sustainability, health, resources, research.

* Harremanetan jartzeko / Corresponding author: Ibon Cancio, CBET Research Group, Dept. Zoology \& Animal Cell Biology; Faculty of Science \& Technology and Research Centre for Experimental Marine Biology and Biotechnology (PiE-UPV/EHU), Areatza pasealekua, 47 (Plentzia, Bizkaia). - ibon.cancio@ehu.eus - https://orcid.org/0000-0003-4841-0079.

Nola aipatu / How to cite: Cancio, Ibon (2021). «Eman ta Zabal Zazu Garapen Iraunkorrerako 14. Helburuaren alde: itsaspeko bizitza... eta bizia»; Ekaia, ale berezia 2021, 247-263. (https://doi.org/10.1387/ekaia.22187).

Jasotze-data: 2020, urriak 20; Onartze-data: 2021, irailak 20

ISSN 0214-9001 - elSSN 2444-3255 / (C) 2021 UPV/EHU

(i) (-) $\odot$ Lan hau Creative Commons Aitortu-EzKomertziala-LanEratorririkGabe 4.0 Nazioartekoa

(c) ${ }_{\mathrm{BY}} \mathrm{NC}$ No lizentzia baten mende dago 


\section{SARRERA}

Espezie gisa, itsasoarekiko gure harremana ez da erraza izan. Horregatik, adibidez, Erdi Aroan, Atlantikoak Mare tenebrosum izena hartu zuen. Beti lurtar mantendu gara kostaldeko baliabideak lehorretik ustiatzen ahalegintzean. Urruntzean, eta Lurra bistaz galdutakoan, itsasoa pasabide soil gisa erabili izan dugu, betiere lurralde berrietarako bidaian. Horretan, Mare nostrum edo Internum mare toki amankomunak sortu ditugu gure edukiontzi kulturalean, itsasoaren jabetza (Mediterraneoarena behintzat) gureganatuz edo nolabait lurtarragoa eginez. Garrantzitsuagoa da oraindik Hugo Grotius filosofo eta legegizon herbeheretarrak XVII. gizaldiaren hasieran plazaraturiko Mare liberum (itsaso askea) lege-araua. Ederra! Garaiko portugaldarraren Mare clausum kontzeptuaren aurka, itsasoa nazioarteko eremu libre eta unibertsal gisa definitu zuen Grotiusek. Baina eremu horren askatasuna hitzaren esanahi sakon osoan gauzatzea bestelakoa da. Legearau hori kontzeptu instrumentala da guztiz, hots, defendatzen du itsasoko altxorrak eskuragarri daudela haietaz balia daitekeen lehenarentzat. Noski, estatu zein gizaki guztiak ez daude berdin hornituak ekonomikoki eta teknologikoki ozeanoetako onurez baliatzeko. Horregatik, XX. mendean, estatu subiranoek beren kostaldeetara loturiko ur-eremuaren (12 itsas milia) gaineko jabetza eta ustiaketa ekonomikorako eskubide osoak (200 milia) eskuratu zituzten, itsasoak eman ditzakeen baliabideak asko direlako. Hala ere, ozeanoen parte nagusiak jaberik gabe dirau; jurisdikzio nazionaletik kanpoko eremuak, ur handiak, indartsu eta ahaltsuenen (ekonomikoki eta teknikoki) esku, eta Nazio Batuek garapen iraunkorrerako plazaratutako 14. helburuak (itsaspeko bizitza) azpimarratzen du ozeanoak beren osotasunean babestu behar direla [1]

Azkenik, artikulu honetan badago beste kontzeptu latindar bat iraunkortasunaren izenean garatuko duguna, Mare incognitum edo «itsaso ezezagun»arena. Hori ere Nazio Batuen erakundean errotu den ideia bat da. Horrela, «Garapen Iraunkorrerako Zientzia Ozeanikoen Hamarkada» izendatu dute 2021-2030ekoa: ikertu, ezagutzeko, eta ezagutu, hobeto babesteko eta era iraunkorrean kudeatzeko [2]. Itsasoa eta haren baliabide biologiko, kimiko zein geologikoak hein handi batean ezezagunak zaizkigu; beraz, itsasoaren inguruko edozein helburuk itsasoaren ikerketa sustatzetik etorri beharko du.

\section{ZERGATIK FOKUA ITSASOETAN? ZER EKARPEN EGITEN DIOTE GURE GIZARTEEN ETA PLANETAREN ONGIZATEARI?}

2012. urtean, «Ocean Health Index» (Ozeanoen Osasun Indizea, OOI) proiektua abiatu zuen nazioarteko diziplina anitzeko zientzialari talde ba- 
tek [3-4]. Proiektuaren xedea une bakoitzean planetako ozeanoen egoera modu ulerkor eta kuantitatiboan aztertzea da. Horretarako, eta une oro osasun-egoera hori neurtzeko asmoz, 120 bat datu-base zientifikotako informazioa erabiltzen dute (alderdi sozial, ekonomiko eta ingurumenekoak integratuz). Urtero, azterketa global bat plazaratzen dute; 2019koa da azken OOI azterketa [4]. OOI indizeak ezartzen duen ozeano osasuntsuen definizioan, ozeanoek jendearentzako zerbitzuak eskaini behar dituztela kontsideratzen da, modu jasangarrian, berdin orain zein etorkizunean. Indizeak zenbait helburu ditu aztergai, hain zuzen ere ozeanoek ematen dituzten zerbitzuak definitzen dituztenak [4]. Zerbitzu horiek elkarrekin aztertuz eta 0-100 tartean markatuz, indizeak ekosistemen egoeraren irudi integratua ematen du. Lehen ebaluazio-tresna izan zen dimentsio biologikoa, fisikoa, ekonomikoa eta soziala zientifikoki neurtzen dituena, nazioarteko hainbat herrialde erabaki-hartzailek itsasoaren erabilera iraunkorrerantz gida gaitzaten. Indizearen arabera, 10 zerbitzu eskuratzen ditugu ozeanoetatik. Hau da, gizakiaren eta ozeanoaren arteko elkarkidetze osasuntsu baterako 10 gizarte-helburu. Zein dira, zehazki?

1. Elikagaien hornidura. Ozeanoetako itsaskiak proteina-iturri garrantzitsua dira. Arrantzuak eta akuikulturak animalia-jatorriko proteinen urteko kontsumoaren $\% 15$ baino gehiago dakarte, eta 4.300 milioi pertsona elikatzen dituzte munduan. Itsas arrantzuak 200 milioi pertsona baino gehiago okupatzen ditu zuzeneko edo zeharkako lan-indar gisa. Arrantzuaren bidezko uzta maximoak lortzeko, espezie objektiboen gehiegizko ustiaketak saihestu behar dira. Arriskuan dauden arrain-populazioetan arreta jarriz ozeanoak etorkizunean ustiatzen jarraituko dugula bermatu behar dugu. Beste alde batetik, akuikultura jasangarriak gehiago parte hartu behar du elikagaien horniduran, baina landutako eremuko uraren kalitatea arriskuan jarri gabe, populazio basatien mende egon gabe (hazitako espezieak elikatzeko edo arrain-stockak berritzeko) eta espezie inbaditzailerik sartu gabe [3-5].

2. Artisau-arrantzurako aukera. Eskala txikian arrantzatu behar dutenei horretarako aukera eman behar zaie. Munduko itsaski-uztaren erdia artisau-arrantzaleen/biltzaileen familiek harrapatzen dute, eta ustiaketa hori etorkizuneko itsaskien baliabideak arriskuan ez jartzeko moduan egin behar da [3-4].

3. Itsas jatorriko produktu naturalak. Produktu natural asko, hala nola koloratzaileak, antioxidatzaileak, norberaren zaintzarako produktuak, probiotikoak, nutrazeutikoak, karbohidratoak, lipidoak, entzimak edota botikak, itsas bakterio, onddo, alga zein animalietatik lor daitezke [5]. Adibidez, PharmaMar espainiar enpresak Aplidina (Plitidepsin) peptido ziklikoa lortu du Aplidium albicans aszidia itsastarretik, eta COVID-19aren aurkako borrokan eragin- 
korra suerta daitekeen farmakoa da. Farmako horrekin, 1987an HIESaren pandemian gertatutakoa errepika daiteke: Estatu Batuetako Elikagai eta Sendagaien Administrazioak HIESaren aurkako lehen terapia onartu zuen, itsas belakietatik erauziriko nukleotidoen analago baten antzera sintetizaturiko konposatu erretrobiral batekin. Azidotimidina (edo zidovudina) du izena, eta Munduko Osasun Erakundeak funtsezko drogen zerrendan sartu zuen. Gaur egun irabazi gehien sortzen dituzten farmakoetako bat da [6].

4. Karbono-biltegia izatea. Karbonoa xurgatzen duten habitatak zaintzea ezinbestekoa da. Itsas larreek, padurek eta mangladiek karbono kantitate handia metatzen dute sustrai, zurtoin eta hostoetan, eta mendeetan zehar gordetzen sedimentuan. Habitat horiek aldatu edo suntsitzen badira, karbonoa airera iristen da, batez ere $\mathrm{CO}_{2}$ modura, eta horrek negutegi-efektua areagotuko du. Ozeanoek gizakiek sortutako karbono dioxidoaren \% 30 inguru xurgatzen dute, hots, berotze globalaren eraginak arintzen dituzte [3-4].

5. Kostaldeko babesa eskaintzea. Zenbait habitatek, hala nola mangladiek, itsas belardiek, padurek, koral tropikalen arrezifeek eta itsasoko izotzek, ekaitz-olatuen eta uholdeen aurka babesten dituzte kostaldeak. Beraz, ezinbestekoak dira biziak eta propietateak salbatzeko [3-4].

6. Turismoa eta aisialdia. Kostako eta itsasoko turismoa ekonomiaren funtsezko jarduera bat da herrialde batzuetan. Kostako turismoa munduko ekonomiaren merkatu-segmentu handiena da: munduko barne-produktu gordinaren (BPG) $\% 5$ dagokio, eta munduko enpleguaren \% 6tik \% 7ra bitartean sortzen du. Itsasoan egiten den turismoak beste balio erantzi bat eskaintzen du, hain zuzen ere kostaldea gozatzetik sortzen den esperientziari lotua dagoena [3-4].

7. Kostaldeko bizibideak eta ekonomia. Ozeanoek mundu osoko kostaldeko komunitateei bizibide eta ekonomia egonkorrak eskaintzen dizkiete. Kalkuluen arabera, Estatu Batuetan ozeanoen jarduera ekonomiko globala 3 eta 6 bilioi dolar (anglosaxoi) bitartekoa da, eta munduko ekonomiari modu esanguratsu askotan laguntzen dio, BPGaren \% 5 inguru dagokion heinean. Munduko merkataritzaren $\%$ 90ean itsas garraioa erabiltzen da, eta itsaspeko kableek telekomunikabide guztien \% 95 garraiatzen dituzte. Mareak, olatuak eta itsasoko energia eolikoak energia-iturri berriak dira, eta aukera handiak dituzte karbono-emisio gutxiko energia lortzeko itsasertzeko herrialde askotan [3-7].

8. Lekuari itsatsitako sena. Pertsonek ozeanotik hurbil bizitzearen inguruko identitate bat garatzen dute, eta horrek berebiziko balioa du [3-4]. Era berean, bisitari soil gisa ere konexioa ezartzen da kostaldeko lekuekin, edo, besterik gabe, leku horiek eta leku horietako espezie bereizgarriak existitzen direna jakiteak berotasuna 
ematen du. Espezie ikonikoek eta leku bereziek onura kultural, espiritual zein estetiko ukiezin batzuk sinbolizatzen dituzte. Zein da Gaztelugatxeko Donieneren balioa bermeotar edo bakiotar batentzat? Zein da haren balioa euskal herritar batentzat? Zein, Tronuen dema telesailaren jarraitzaile sutsu batentzat? Zein da lanpernaren balioa euskal edo galiziar kostaldeko biztanle batentzat? (1. irudia)
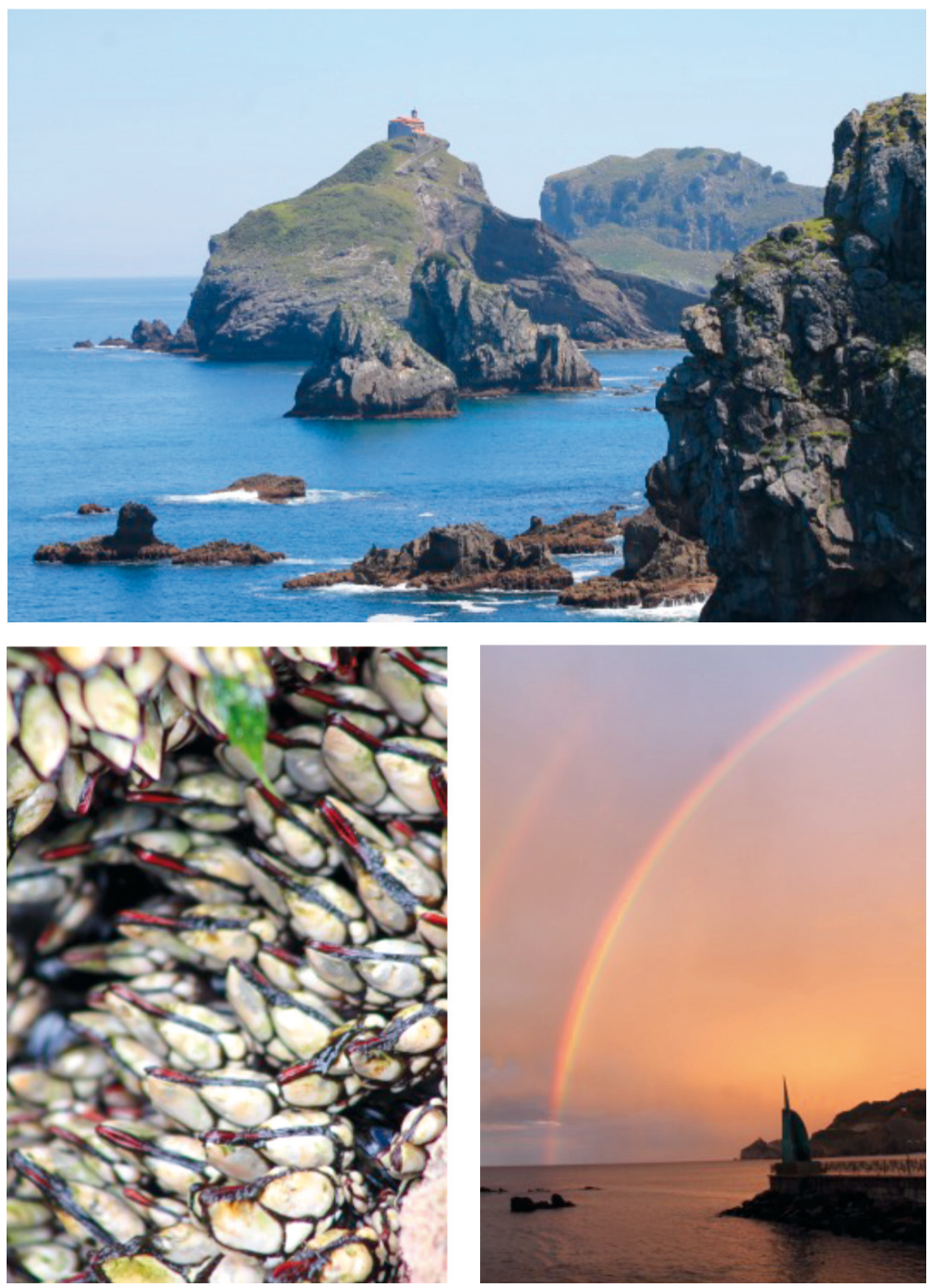

1. irudia. Gaztelugatxeko Donieneren argazkia Atxulotik, biotopo babestuaren mugatik. Zein da toki horren balioa? Zein da lanperna espeziearen balioa hango biztanleentzat? Non kokatzen da ortzadarraren urrezko lapikoa? 
9. Ur garbiak. Uraren kutsadurak kalte egiten die giza osasunari, bizitzari eta ingurumen-osasunari. Hori dela eta, helburu komuna zera da: produktu kimikoek eragindako kutsadura, alga toxikoen ugaritzea, gehiegizko mantenugaiak egotea (eutrofizazioa) eta sedimentuen, patogenoen eta zaborraren sorrera gutxitzea [3-4]. Erreferentzia-puntuak zero kutsadura izan behar du, ingurumenosasunaren barruan baitago gizakiaren osasuna ere.

10. Biodibertsitatea. Itsas ekosistemen aniztasuna izugarria da, eta haien osasuna babestea ezinbestekoa da aurreko helburuak erdiesteko eta zerbitzuak lortzeko. Hiru mila milioi pertsonaren baino gehiagoren mantenua itsasoaren eta kostaldearen biodibertsitatearen mende dago, zuzen-zuzenean. Ozeanoetan, ia 200.000 espezie identifikatu dira, baina gehienak ezezagunak zaizkigu oraindik [3-5, 7].

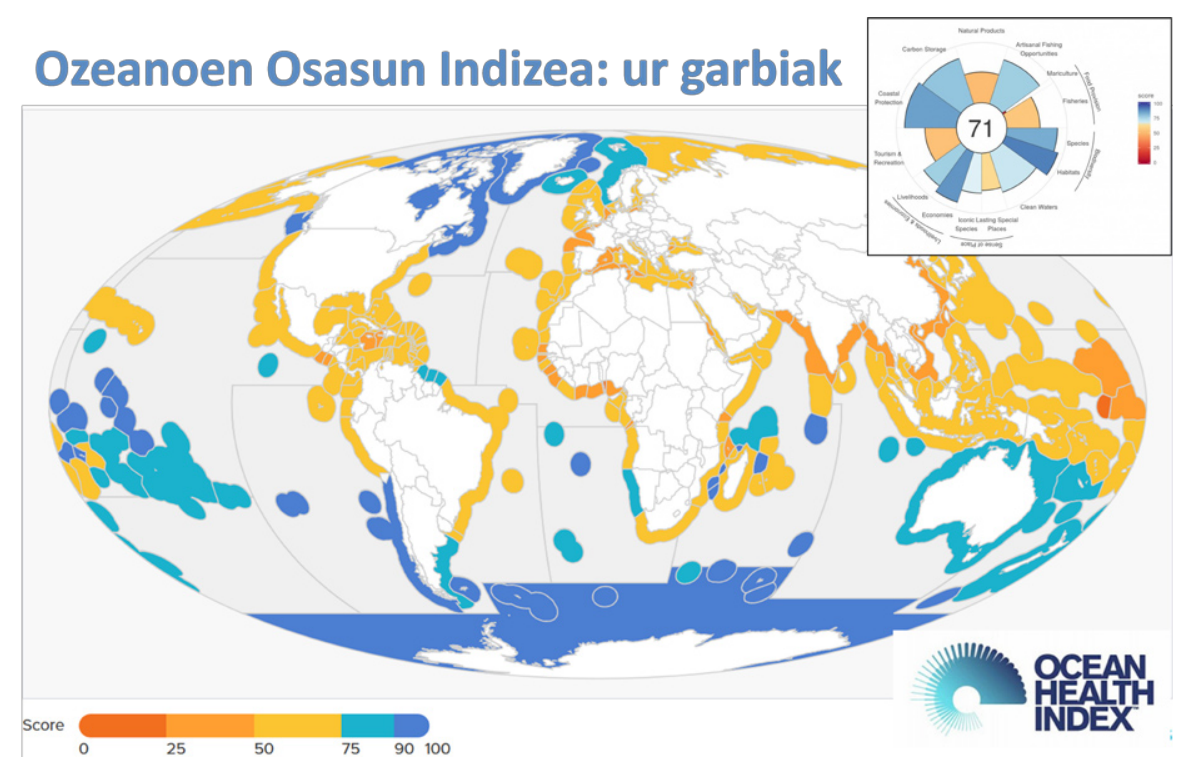

2. irudia. Ozeanoen Osasun Indizearen 2019ko emaitza globala: 71 puntu [4]. Ur garbien helburuarekin loturiko egoera 2019an, herrialdez herrialde eta eremuz eremu (urdina: oso ongi; gorria: gaizki). 2021 ean ez da oraindik 2020ko daturik plazaratu.

2012an, OOIren puntuazioa globalki 100tik 60koa izan zen (36-86 bitartean, lurraldearen arabera). Orokorrean, lurralde aurreratuek garapenbidean daudenek baino puntuazio hobeak lortu dituzte. Lurraldeen $\% 5 \mathrm{ek}$ bakarrik lortu zituzten 70 puntu baino gehiago, eta $\% 32 \mathrm{k} 50$ puntu baino gutxiago [3]. 2015. urtean, ordea, garapen iraunkorrerako helburuak plazaratu zirenean, zein izan zen mundu-mailako indizea? Bada, 71 ra igo zen, eta hor mantendu da harrezkeroztik (2. irudia). Eta zer puntuazio eskuratu 
dute Espainiako eta Frantziako estatuek? Espainiak 68, eta Frantziak 72 (rankingeko 106. eta 64. estatuak dira, 2019. urtean argitaratutako azken txostenaren arabera). Biak ala biak oso gaizki ebaluatuak izan dira ur garbien esparruan: 49 eta 48 puntu lortu dituzte, hurrenez hurren, helburua den 70eko puntuaziotik urruti [4]. OOI indizeak esparru nazionaletatik at kokatzen diren itsas eremuen egoera ere aztertzen du, baina emaitza horiek datu bilduma eskasagoetan oinarritutako azterketen ondorio dira. Egoera horretan, 2015ean, Nazio Batuek garapen iraunkorrerako helburuak plazaratu zituzten, eta ozeanoak ardatzean jarri zituzten 14. helburuan.

\section{ITSASPEKO BIZITZA: 14. HELBURUAREN ZEHARKAKOTASUNA}

Garapen iraunkorrerako 14. helburuak zenbait jomuga edo itu jarri ditu mahai gainean (1. taula) [1]. Ozeanoak, haien tenperaturaren, konposizio kimikoaren, korronteen eta izaki bizidunen horniduraren arabera, sistema globalen motorra dira, eta, haiei esker, Homo sapiens espezieko kideoi zein bestelako bizidunei bizitzeko egokia suertatzen zaigu planeta hau. Horrez gain, klima-aldaketako garai hauetan, argi dago ozeanoak eta itsasoak funtsezkoak direla gure gizarteen ongizaterako. Munduko populazioaren $\% 40$ baino gehiago (3.100 milioi pertsona) itsasotik 100 kilometrora baino gutxiagora bizi da, 150 bat herrialdetan banatuta [1]. Euskal herritarron ia $\%$ 100entzat egia da hori; Nafarroako Erriberako biztanle batzuk soilik bizi dira urrunago. Itsasertza izan zein ez, herrialde guztiak ozeanoekin eta itsasoekin zuzenean lotuta daude, ur kontinentalen bitartez.

Eskaintzen diren baliabide guztien artean, esan daiteke 14. helburua zeharkakoena dela [1], iraunkortasunaren beste 16 helburuei ekarpenak egiten dizkien heinean (3. irudia). Arrantzuak, akuikulturak eta itsas baliabide biologikoen inguruko ikerketek aukera handiak eskaintzen dituzte gosea gutxitzeko, eta giza eta ingurumen-osasuna hobetzeko, pobrezia arintzeko, hazkunde ekonomikoa sortzeko, gure planeta babesteko eta hazkunde kohesiboa eta inklusiboa bermatzeko. Akuikultura da azkarren hazten ari den elikagaien sektorea, eta hazten ari den populazioaren eskaerari erantzuteko adina itsaski ekoizteko ahalmena du. Hala ere, munduko arrain-populazioaren \% 30 gehiegi ustiatuta dago, eta errendimendu jasangarritik urrun gaude [1]. Ozeanoek giza jarduerek sortutako $\mathrm{CO}_{2}$-aren $\% 30$ inguru xurgatzen dute, hots, berotze-efektua leuntzen laguntzen dute. Baina horrek itsasoa azidoagoa bilakatu du; zehazki, azidotasuna \% 26 handitu da industria-iraultzaren hasieratik [1]. Itsasoko kutsadura, gehienbat lurreko iturrietatik datorrena, maila kezkagarrietara iritsi da. Lehen, metalak, petrolioa, konposatu organiko iraunkorrak eta hondakinen jariaketak ziren kezka-iturri; orain, aldiz, plastikoa bilakatu da ozeanoetako arazo nagusia, edo mediatikoa. Hala, ozeanoko kilometro karratu bakoitzeko batez beste 
1. taula. Itsaspeko bizitzaren garapen iraunkorrerako helburuak markatzen dituen jomugak [1] eta bakoitzak ematen dituen ozeano-zerbitzuak.

14. helburuaren jomuga zehatzak
14.1. 2025erako itsas kutsadura mota guztiak saihestea eta nabarmen
murriztea, bereziki lurrean egindako jarduerek eragindakoa, itsasoko de-
trituak eta mantenugaien bidezkoa.
14.2. 2020rako itsasoko eta kostaldeko ekosistemak modu iraunkorrean
kudeatzea eta babestea, kontrako ondorioak saihestuz eta erresilientzia
indartuz ozeanoen osasuna eta produktibitatea berrezartzeko.

14.3. Ozeanoen azidotzearen ondorioak minimizatzea maila guztietan, lankidetza zientifiko handiena sustatuz.

14.4. 2020rako arrantzu-ustiapena eraginkortasunez arautzea. Gehiegizko, legez kanpoko, aitortu eta arautu gabeko arrantza eta arrantza-jarduera suntsitzaileak amaitzea, eta oinarri zientifikoko kudeaketa-planak aplikatzea arrain-populazioak ahalik eta eperik laburrenean berrezar daitezen. Gutxienez, arrantzaren errendimendu jasangarri handiena eragin dezaketen arrain-mailak lortzea, haien ezaugarri biologikoen arabera.

14.5. 2020rako gehiegizko, legez kanpoko edota aitortu eta arautu gabeko arrantzari laguntzen dioten dirulaguntzak debekatzea. Halaber, beharrezkoa da garapen-bidean eta gutxien garatuta dauden herrialdeei tratu berezia, egokia eta eraginkorra ematea Munduko Merkataritza Erakundearen esparruan, arrantzarako dirulaguntzei buruzko negoziazioan.

14.6. 2020rako itsasertzeko eta itsasoko eremuen \% 10 gutxienez kontserbatzea, nazioarteko zuzenbidearekin bat datozen legeekin bat eginez eta eskura dagoen informazio zientifiko hoberenean oinarrituta.

14.7. 2030erako garapen-bidean dauden uharteek eta gutxien aurreratutako herrialdeek itsas baliabideen erabilera jasangarritik lortzen dituzten onura ekonomikoak handitzea, bereziki arrantzaren, akuikulturaren eta turismoaren kudeaketa iraunkor baten bidez.

14.A. Ozeanoen osasuna hobetzeko eta itsas biodibertsitateak garapenbidean dauden herrialdeen garapenari egiten dion ekarpena sustatzeko ezagutza zientifikoa handitzea, ikertzeko gaitasuna garatzea eta itsas teknologia transferitzea.

14.B. Artisau-arrantzaleei itsas baliabideak eta merkatuak eskuratzen laguntzea.

14.C. Ozeanoen eta haien baliabideen kontserbazioa eta erabilera jasangarria hobetzea, Itsas Zuzenbideari buruzko Nazio Batuen Konbentzioan jasotako zuzenbidea aplikatuz.
Emandako zerbitzuak

Ur garbiak

Biodibertsitatea, produktu naturalak

Karbono-biltegia

Elikagaien hornidura, biodibertsitatea

Elikagaien hornidura, artisau-arrantzuaren aukera

Kostaldearen babesa, leku-sena, ur garbiak, biodibertsitatea

Elikagaien hornidura, turismoa/ aisialdia, bizibideak/ ekonomia

Biodibertsitatea, produktu naturalak, ur garbiak, bizibideak/ekonomia

Artisau-arrantzua

Elikagaien hornidura, biodibertsitatea, produktu naturalak 
13.000 plastikozko zati omen daude, Nazio Batuek garapen iraunkorraz emandako informazioaren arabera [1]. Baina kostaldeko urak eutrofizazioaren ondorioz ere ari dira hondatzen [8]. Ahalegin hitzarturik gabe, espero da itsas ekosistema handietan kostaldearen eutrofizazioa $\% 20$ handitzea 2050erako [1]. Hala, zenbait itsasgune «eremu hilak» (hipoxiaguneak) izendatu dira, oxigeno eskasia dela eta; besteak beste, Mexikoko eta Omaneko golkoetan edota Baltikoan eta Murtziako Mar Menorren [8]. Kutsadura-egoera horrek giza osasuna baldintzatzen du.
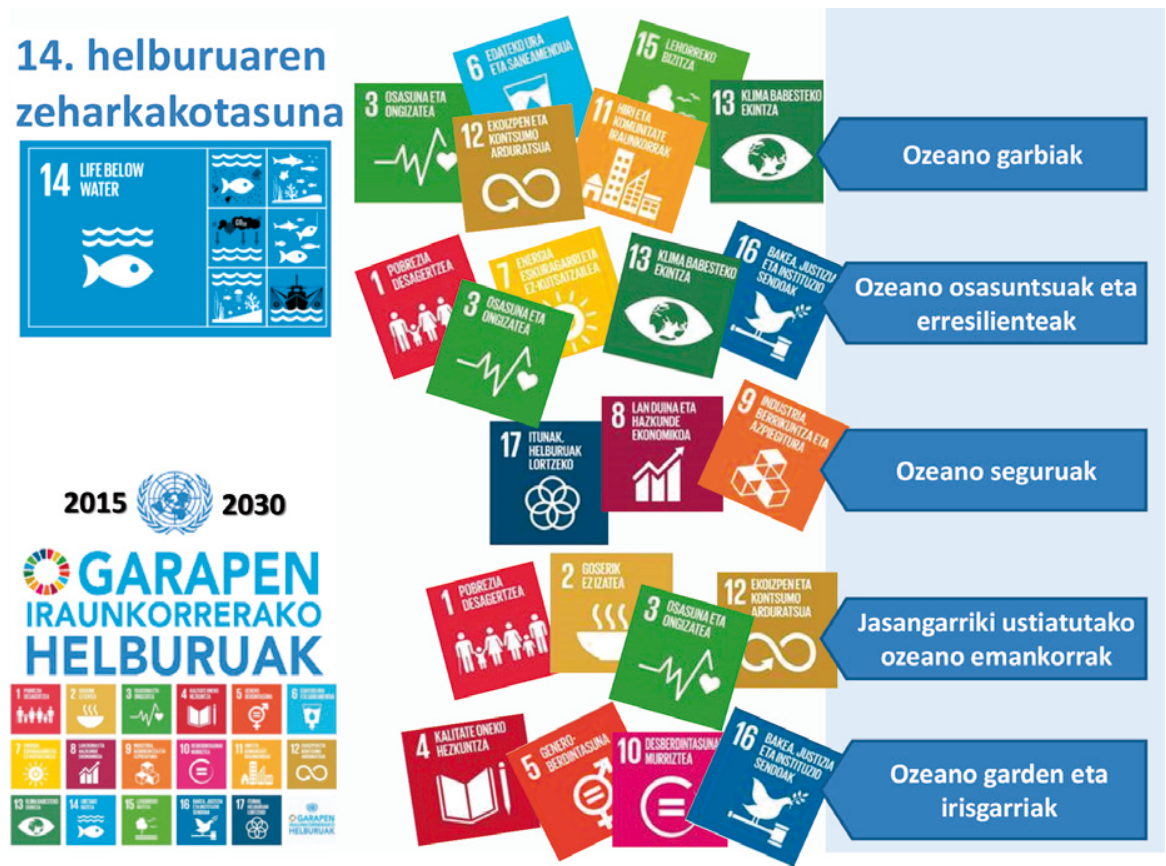

3. irudia. Garapen iraunkorrerako 14. helburuaren zeharkakotasuna eta gainontzeko helburuei egiten dien ekarpena.

Garapen iraunkorrerako helburuek itsasoko eta kostaldeko ekosistemak lurreko gehiegizko arrantzutik, kutsaduratik eta azidotzetik babesteko marko legala sortu dute [1]. Nazioarteko zuzenbidearen bitartez, ozeanoetako baliabideen kontserbazioa eta erabilera jasangarria hobetzea lortu nahi da, eta lagungarria izango da, baita ere, ozeanoek aurrez aurre dituzten erronka batzuk arintzeko. Itsas eremu babestu gehiago sortu behar dira, eta modu eraginkorrean kudeatu, eta horretarako beharrezkoak diren baliabideak izan behar ditugu $[1,9]$. 
Arrantzu jasangarria, energia berriztagarrien ekoizpena, ekoturismoa eta halako jardueren bidez, herrialdeek beren enplegu-tasak eta saneamendurako azpiegiturak handitu dituzte, eta, aldi berean, pobrezia, malnutrizioa eta kutsadura murriztu. Ozeanoetan oinarritutako ekonomiek aukera gehiago ematen dituzte emakumeak ahalduntzeko, haiek osatzen baitute itsas arrantzuko eta akuikulturako bigarren mailako jardueretako lan-indar gehiena. Emakumeen enpleguaren hazkundeak bizitasun ekonomiko handiagoa eman die komunitate txiki eta bakartuei, eta emakumeen egoera hobetu du garapen-bidean dauden herrialdeetan. Adibide xumea, baina ona, Euskal Herriko Itsas Garapen Elkarteko [10] emakumeen ekarpen berezitua dugu, Euskadiko Itsasoko Emakume Langileen Federazioaaren parte hartzearen bidetikere elkarteko da.

Era berean, kostako eta uharteetako populazioak dira klima-aldaketak gehien kaltetzen dituenak. Maizago eta intentsitate handiagoz jasaten dituzte muturreko fenomeno klimatikoak, hala nola urakanak, zikloiak eta tifoi indartsuak, eta ozeanoen azidotzearen, itsas mailaren igoeraren eta ozeanoen gazitasunaren mende daude. Aldaketa horiek kostan ez ezik barrualdean ere nabarituko dira, itsaslasterrek sistema meteorologikoetan eragiten dute eta. Kalkulatu da 2050erako munduan 50-200 milioi pertsona lekualdatu beharko direla klima-aldaketaren ondorio negatiboengatik, eta horrek arriskuan jarriko dituela elikagaien segurtasuna, bizibideak eta gizarte-egonkortasuna [1]. Beharrezkoa da egokitzen eta hobetzen jarraitzea, larrialdietarako prestaketari laguntza handiagoa emateko, bai eta alerta-sistema goiztiarrak eta kostako eremuen antolamendurako ere.

\section{GARAPEN IRAUNKORRARI BURUZKO TXOSTENA ETA 14. HELBURUA}

Garapen iraunkorrerako helburuen arrakasta, neurri handi batean, monitorizazio-, berrikuspen- eta jarraipen-prozesu eraginkorretan oinarritu behar da. Bost urte igaro dira onartu zirenetik, eta 10 urte gelditzen zaizkigu helburuen gauzatzea 2030. urtera arte, horixe baita helburuak gauzatzeko muga. Nola ari gara garatzen eta gauzatzen 14. helburuko ituak eta jomugak? Ba al dago helburuen lorpenen eta betetze-mailen gaineko behaketa edota jarraipen independenterik?

Garapen iraunkorrari buruzko txostenean [11-12], helburuen lorpenari dagokionez zer egoera dugun aztertzen da. Milurtekoko garapen-helburuek estandarrak ezartzen dituzte, garatze-bidean dauden herrialdeentzat ez ezik baita herrialde industrializatuentzat ere. Gobernuek eta gizarte zibilak txosten hori erabil dezakete ekintza-lehentasunak identifikatzeko, ezarpenerako funtsezko erronkak ulertzeko, aurrerapenen jarraipena egiteko, kontuak ematea bermatzeko eta 2030erako helburuak lortzeko bete behar diren hu- 
tsuneak identifikatzeko. OOI indizea hartzen du txostenak oinarri gisa, eta, 14. helburuaren azterketan, indizeak berebiziko garrantzia du.

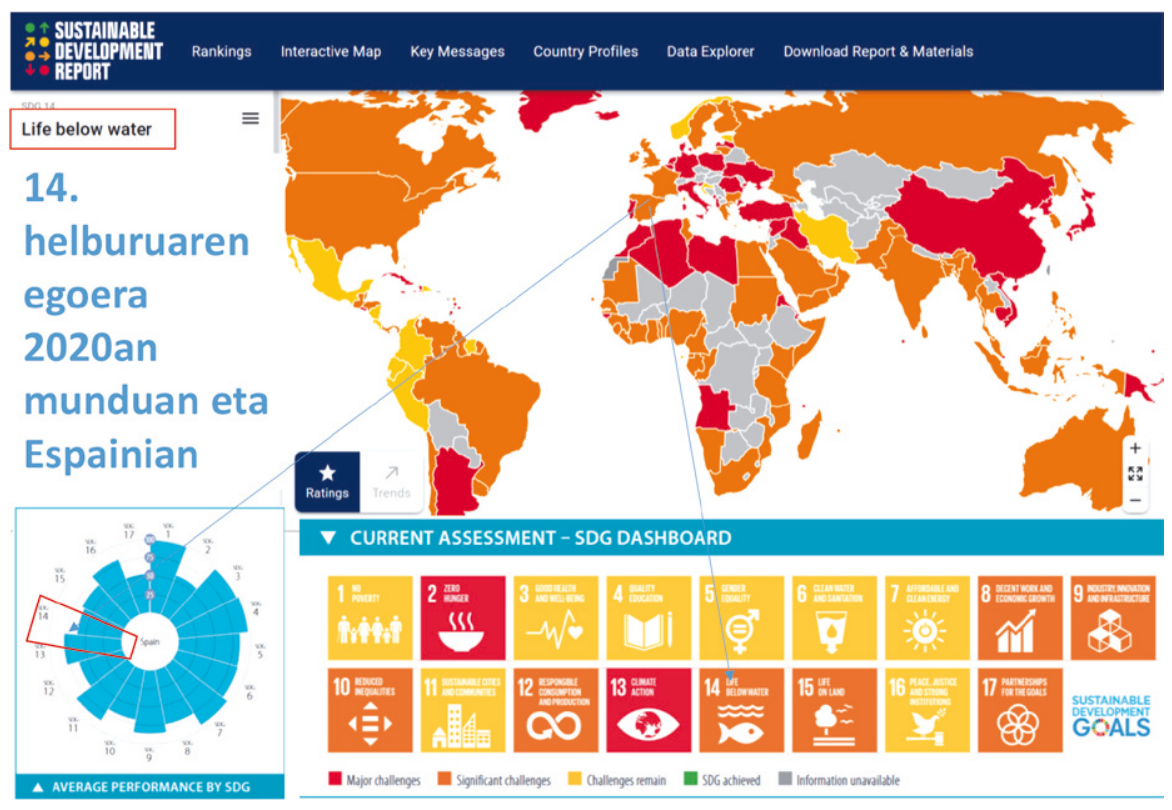

4. irudia. Garapen iraunkorraren emaitzak 2020. urtean munduan eta Espainiako estatuan. Osasun-indizearen emaitza globala 2019an: 71 puntu [12]. Mapak 14. helburuak munduan bizi duen egoera adierazten du, txostenean azaltzen den bezala.

Txostenak mundu-mailako eta herrialdez herrialdeko urteroko emaitzak eta rankingak argitaratzen ditu, une oro eta urtez urte aldatzen diren aldagaiak (datuen eskuragarritasunaren arabera) kontuan hartuta helburu bakoitza neurtzeko (4. irudia). Espainiaren ebaluazioak batez besteko 78,1 puntuko emaitza eman zuen 2020. urtean (rankingeko 22. estatua), eta 79,46koa 2021. urtean (20. estatua) [12]. Baina, 14. helburuari dagokionez, egoera oso kezkagarria da, eta kolore laranjarekin azpimarratu da: «Erronka esangarriek bere horretan diraute» [12]. Frantzia, orokorrean, hobeto dago, guztira 81,1 eta 81,67 puntu eskuratu baititu azken bi urteo$\tan$ (8. estatua da), baina, 14. helburuan, Espainiaren antzera dabil, eta, 2021. urtean, gaizkiago [12]. Txostenaren arabera, zer moduz darabil Lurrak 14. helburua? Ba ez oso ongi! Azterketen arabera, 14. helburuak du puntuaziorik txarrena (4. irudia) [12]. Orokorrean, itsasoaren inguruan eskuratu daitezkeen datuak oso murritzak dira, eta sakabanatuak daude. Datuetan, helbururik pobreena da gurea 17 ren artean, eta neur daitezkeen 
adierazleak gutxi dira: babesturiko guneen azaleraren ehunekoa, lurralde bakoitzak arraste bidez hartzen duen arrantzu-kuotaren ehunekoa, lurralde batek bere eremu ekonomiko esklusiboaren barruan (200 itsas milia) gainustiatzen edo arrantzatzen duen arriskupeko espezieen ehunekoa, eta OOI indizearen ur garbien azpihelburuaren puntuazioa.

Adibide errazak jarriko ditut horren harira, eta gurera ekarriz. Azken urteetan, kutsatzaileen inguruko kudeaketa bortitza ezarri da; lehenik, kutsatzaile organiko iraunkorren (bifenilo poliklorinatuak, DDT, aldrina, klordanoa, lindanoa...) aurka egin zen, Stockholmeko eta Genevako konbentzioen bitartez; gero, Europako araudia onartu zen, 2000ko Uraren Esparru Zuzentarauaren eta Itsas Estrategiari buruzko Esparru Zuzentarauaren bitartez [13]. Euskal Herrian, eredugarriak izan ziren Bilboko itsasadarreko urak garbitzeko 1990eko hamarkadan hasita hartutako neurriak eta erdietsitako emaitzak. Kutsatzaile tradizionalen mailak nabarmenki jaitsi dira, baita euskal kostaldeko beste itsasadar guztietan ere, eta oxigeno-mailak berreskuratu dira Nerbioi-Ibaizabal itsasadarreko uretan [13-14]. Zuzentarauak metalen eta ardurako zenbait konposaturen gainean jarraipena egitea agintzen du [13-14]. Haietako asko ez omen dira jadanik lehen bezain kezkagarriak. Baina kutsatzaile berriak azaldu zaizkigu kezka-iturri gisa. Hala, adibidez, Gernikako itsasadarrean bizi diren arrainen ale arrak feminizazio-prozesuak pairatzen ari dira, eta arrautzak ekoizten dituzte beren testikuluetan, konposatu xenostrogenikopean egoteagatik [15]. Non daude konposatu horiei (alkilfenolak, farmako estrogenikoak, esterolak, parabenoak, pestizidak, lurrinak...) buruzko datu jarraituak? Petrolio-isuriak ez dira orain kezka nagusia. Aspaldian, gure hondartzarako bisitetan, ez dugu hondarrean arakatzen ibili behar oinetako galipot-zipriztinak ekidin nahian. Orain, plastikoak dira kezka, eta asaldatu egiten gara noizean behin gure kostaldeko zenbait irudi ikustean. Baina ba al dugu datu zehatzik? Ez dakigu zehazki zenbat plastiko metatzen den gure Bizkaiko Golkoan, ezta horren eragina zein izan daitekeen ere!

Beste adibide bat. Bioteknologia urdina edo itsas bioteknologia itsas baliabide biologikoetatik produktuak lortzean datzan jarduera teknologiko eta sozioekonomikoa da. Nazioartean, etorkizuneko ekonomiaren sustapenean ekarpen garrantzitsua egin dezakeela onartzen diote erakundeek. Europako Batzordeak (Europako Elkarteko Itsas Arazoetarako eta Arrantzurako Zuzendaritza Orokorra, DG Mare) itsasguneen garapen sozioekonomikorako bost jarduera berrien artean kokatzen du bioteknologia urdina [16]. OECDk ere bederatzi itsas jarduera ekonomiko garrantzitsuenen artean sartu du bioteknologia. 2030erako Ozeanoen Ekonomia txostenean [17], bederatzi jardun horien gaineko ibilbide-orria argitaratu zuen, estatistika zehatzez lagundua. Dena den, ez zuen inongo daturik eman itsas bioteknologiako jardueren inguruan, haien mugak oso lausoak direlako. Jarduerek askotan ez dute «urdin» edo «itsas» etiketarik hartzen. Biotekno- 
logia dira, besterik gabe. Jar diezaiogun arreta, adibidez, biomedikuntzaren arloari. Ziklinak eta ubikuitina, gaur egungo minbiziaren aurkako azterketa molekularraren ikerketa-esparrua hazi dzuten proteina edota polipeptidoak (2001eko eta 2004ko Nobel sariak), itsas animaliak (itsas trikua eta muxila) eta itsas estazio biologiko baten azpiegiturak (Woods Hole Marine Biological Laboratory) baliatuz aurkitu ziren. Bada, minbiziaren aurkako ikerketa molekularraren arloan, zer zati onartzen da itsas jatorrikoa dela? Zein da itsas produktu naturalen ekarpena eta, beraz, itsas biodibertsitatearena, mundu-mailako ekonomian? Jarduera bat sustatzeak datu-bilketa minimo bat behar du.

\section{Babestutako itsas-eremuak}

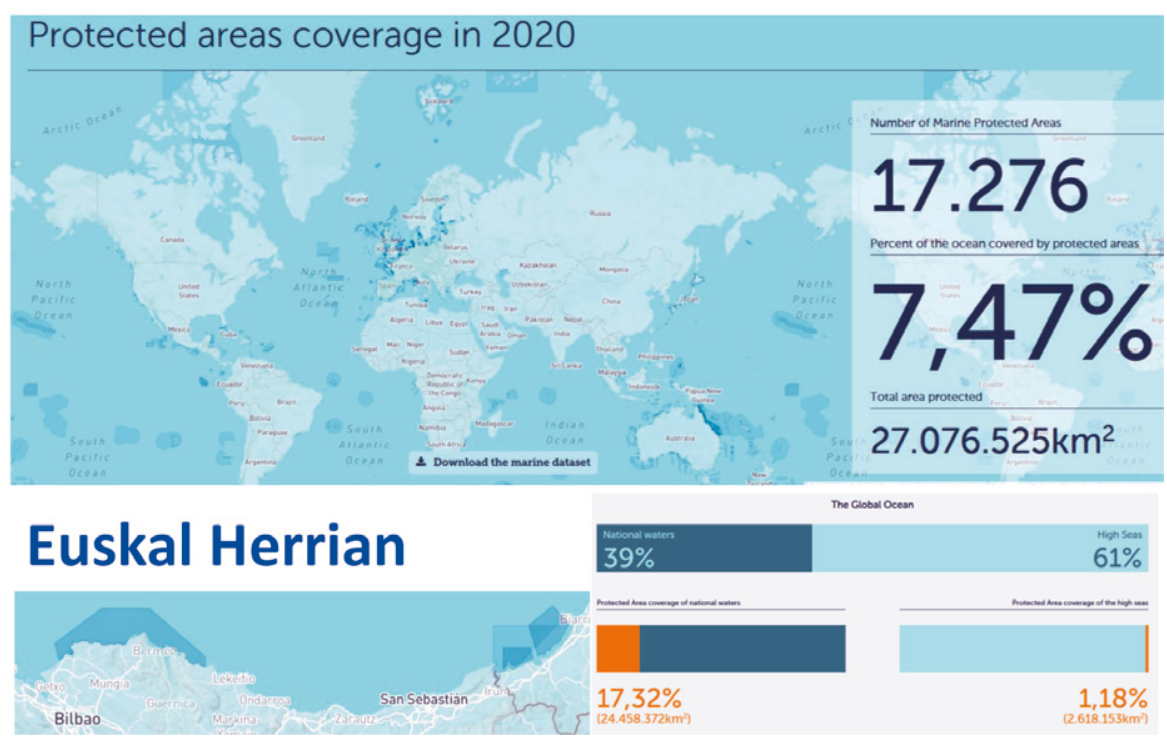

5. irudia. Munduko eta Euskal Herriko itsas eremu babestuen banaketa eta haien estalduraren ehunekoak «Protected Planet» datu-basean [9], 2020ko irailean.

Itsas eremu babestuen azalera erraz neurtzen den zerbait da. Badugu horren jarraipena egiten duen datu-base bat [9], eta, 2020ko irailean argitaraturiko datuen arabera, itsas azaleraren \% 7,47 dago babestua (5. irudia), modu bateko edo besteko babes-mekanismo eta araudien bitartez. Jomuga $\%$ 10ekoa zen 2020rako. Ez gara ailegatu, eta, 2021eko irailean argitaraturiko berrazterketaren arabera, \% 7,72ra igo da soilik itsas azalera babestua. Beste alde batetik, eremu horien estaldura oso desberdina da ur-eremuen kokapenari erreparatzen badiogu. Itsasoaren \% 39 herrialde baten edo besteren «lurralde»an kokatzen da, UNCLOSek (Itsas Zuzenbideari Buruzko 
Nazio Batuen Konbentzioa) 1982. urtean onartu bezala. Britainia Handiaren eta Islandiaren arteko bakailaoaren gerrateen ondoren, eta lurralde txiki batzuen eskariei jarraikiz, lurralde bakoitzak bere kostaldeko baliabideen jabegoa eta ustiapenerako eskubidea ditu (kostaldeko 12 eta 200 itsas miliatan). Inoren jabegoaren pean ez dauden urek planetaren itsas azalera osoaren \% 61 estaltzen dute, eta soilik \% 1,18 dago babestua 2021ean. Badago hor zer ikasia. Nork jarriko ditu baliabideak norberarena - eta solik norberarena- ez dena babesteko? Baina begira ditzagun gune babestuak orokorrean. Zer informazio ematen da, zer jarraipen egiten da babesguneen kudeaketaz? Har dezagun euskal kostaldea. Babesturiko guneek esparru handia osatzen dute mugaz bi aldetara (5. irudia), baina kostaldera oso lotuak dira. Lapurdin, ia itsasertz osoa dago babestua, Hegaztien $\mathrm{Zu}$ zentarauaren bidez batik bat ( «Bidasoako itsasadarra eta Hondarribiako badia», batetik, eta «Miarritzeko arrokak: Bouccalot eta arroka biribila», bestetik, biak 2019tik), edo Habitaten Zuzentarauaren eskutik («Donibane Lohizuneko eta Miarritzeko itsaslabarrak», 2007tik). Oso interesgarria da nazioarteko OSPAR konbentzioaren arabera (Atlantikoko Ipar-Ekialdeko Itsas Ingurumena Babesteko Konbentzioa) «Euskal kosta harritsua eta haren hedadura itsas zabalean» itsasgune babestua dela 2012tik. Zer daukagu hegoaldean? Eremu zabal bat babestua dago, baina bakarrik Hegaztien $\mathrm{Zu}$ zentarauaren barruan: «Mundakako itsasadarra-Ogoñoko itsasmuturreko itsasgunea», «Urdaibaiko itsasadarra» eta «Txingudi». Gainera, Habitaten Zuzentarauak hiru biotopo berezi babesten ditu: «Gaztelugatxeko Doniene» (1. irudia), «Urdaibaiko itsasertza eta padurak» eta «Deba-Zumaiako itsasertza». Eremu horietan egiten den jarraipenean dago gakoa. Nahikoa al da? Zer emaitza ematen ditu? Kudeaketa-planak behintzat badaude, beste babesgune askotan ez bezala. Beste alde batetik, Euskal Herrian babesturiko itsas azalera gehiena Hegaztien Zuzentarauaren barruan soilik egotea agian ez da nahikoa.

Mundu-mailako ezjakintasun, datu falta, jarraipen ez horren inguruan zerbait egin beharra dago. Nazio Batuek berehala hartu zituzten horren inguruko lehen neurri zuzentzaileak. Ezin da zaindu ezagutzen ez dena. Beraz, ikerketan jarri behar da indarra. Horren harira, eta UNESCOko Gobernuen Arteko Batzorde Ozeanografikoaren (IOC) bitartez, «Garapen Iraunkorrerako Zientzia Ozeanikoen Hamarkada» izendatu du 2021-2030 bitarteko epea [2].

Leku egokian momentu egokian egotea gauza askotarako gakoa da. Hori egia biribila da zientziarentzat, baita ere organismoentzat, zeren eboluzioan zehar azaltzen dituzten egokitzapenak lekuari eta momentuko baldintzei loturik daude. Ikerketa eta ozeano-zientzia hobea eta globalagoa egitetik etorriko da ezagutza. Nazio Batuen hamarkada honetako misioaren azterketak erakusten du itsas ikerketako azpiegiturak funtsezkoak izango direla erakundearen asmo handiko planak gau- 
zatzeko. «Behar dugun zientzia nahi dugun ozeanoarentzat» dio leloak. Nazio Batuen xede horren elementu nagusia «Jakintza zientifikoa garatzea, azpiegiturak eraikitzea eta ozeano iraunkor eta osasungarri baterako harremanak sustatzea» da [2]. Argi dago hori guztiz koherentea dela itsas estazio biologikoek ikerketa-azpiegitura independente gisa eta EMBRC-ERIC [5, 7, 18] nazioarteko ikerketa-azpiegitura europar (non PiE-UPV/EHU baita Espainiako estatuko ordezkaria) gisa aurreikusitako jarduera zientifiko zirraragarriekin. Hona hemen Nazio Batuen proposamenaren xehetasunak:

- 2030 Agendarako ozeanoen inguruko lehentasun kritikoak izan daitezkeen gaien inguruan zientzialariak mobilizatzea.

- Arlo ozeanikoan ikerketa-esparru berriak eta lankidetza bateratuak sustatzea.

- Ikerketa-esparruen sintesia egitea, eta lan-ildoak ezartzea, ezagutzaarrailak eta ikerketetarako lehentasunak identifikatu ostean.

- Zientziaren, politikaren eta gizartearen arteko zubiak eraikitzea, informazio-fluxuak, komunikazioa eta datuen eskuragarritasuna sustatuz.

- Emaitzak sintetizatzea eta erabiltzaileak bultzatutako irtenbideak garatzea.

- Elkarrekin diseinatutako ikerketa-estrategia berriak garatzea.

Klima-aldaketaren eraginak nozitzen ari garen garai honetan eta sortzen ari diren kalte globalen mehatxuei aurre egiteko itsas baliabide biologiko, fisiko, kimiko zein geologiko berrien premia larrian garenean, ikerlarien eta ikerketa-azpiegituren arteko aliantzak inoiz baino beharrezkoagoak dira. Benetako biziaren «arka» ez da uholde handiaren ostean Lurra birpopulatzeko sortu zen azpiegitura/edukiontzi hura, non espezie bakoitzeko bikote bana aurkitu baitzuten aterpe. Biziaren edukiontzia itsasoa da! Itsasoa, ura eta kresala, Mare infinitum, Mare eternum, Mare iraunkorrum! Eman ta zabal zazu!

\section{ESKER ONA}

Lan hau Assemble+ H2020 Europako proiektuaren (INFRAIA-012016-2017) eta Eusko Jaurlaritzako talde kontsolidatuaren (IT1302-19) barruan egin da. Eskerrik asko Oihane Díaz de Ceriori, testua irakurri ondoren egindako iradokizunengatik. 


\section{BIBLIOGRAFIA}

[1] https://sdgs.un.org/goals/goal14. 2020ko urria.

[2] https://www .oceandecade.org/about?tab=our-vision. 2020ko urria.

[3] HALPERN BS, LONGO C, HARDY D, MCLEOD KL, SAMHOURI JF, KATONA SK, KLEISNER K, LESTER SE, O'LEARY J, RANELLETTI M, ROSENBERG AA, SCARBOROUGH C, SELIG ER, BEST BD, BRUMBAUGH DR, CHAPIN FS, CROWDER LB, DALY KL, DONEY SC, ELFES C, FOGARTY MJ, GAINES SD, JACOBSEN KI, KARRER LB, LESLIE HM, NEELEY E, PAULY D, POLASKY S, RIS B, ST MARTIN K, STONE GS, SUMAILA UR, ZELLER D. 2012. «An index to assess the health and benefits of the global ocean». Nature. 488: 615-620.

[4] http://www .oceanhealthindex.org/. 2020ko urria.

[5] PIÑA, M., COLAS, P., CANCIO, I., AUDIC, A., BOSSER, .L, CANARIO, A., GRIBBON, P., JOHNSTON, I., KERVELLA, A.E., KOOISTRA, W.H.C.F., MERCIECCA, M., MAGOULAS, A., NARDELLO, I., SMITH, D., PADE, N., ROBINSON, D., SHOEN, A., SCHULTZ, F., KLOAREG, B. 2018. «The European Marine Biological Resource Infrastructure Cluster, an alliance of European research infrastructures to promote the blue bio-economy» «Grand Challenges in Marine Biotechnology, Grand Challenges in Biology and Biotechnology», 405-421 (editoreak: Trincone, A., Rampelotto, P.H), Springer Verlag. ISBN 9783319690742.

[6] HEFFERNAN, O. 2020. «Help for the high seas». Nature. 580: 20-22.

[7] GRAS, S., PADE, N., KLOAREG, B., CANCIO, I. 2019. «Developing research in maritime regions through innovation ecosystems». Open Access Government, 204: 342-343.

[8] JOYCE, S. 2000. «The dead zones: oxygen-starved coastal waters». Environmental Health Perspectives. 108: A120-A125.

[9] https://www.protectedplanet.net/en. 2020ko iraila.

[10] https://www.itsasgarapen.eus/eu/. 2020ko urria.

[11] SACHS, J., SCHMIDT-TRAUB, G., KROLL, C., LAFORTUNE, G., FULLER, G., WOELM, F. 2020. The Sustainable Development Goals and COVID-19. Sustainable Development Report 2020. Cambridge: Cambridge University Press.

[12] https://www.sdgindex.org/. 2020ko urria eta 2021eko urria.

[13] SOLAUN, O., RODRÍGUEZ, J.G., BORJA, A., GONZÁlEZ, M., SAIZSALINAS, J.I. 2013. «Biomonitoring of metals under the water framework directive: detecting temporal trends and abrupt changes, in relation to the removal of pollution sources». Marine Pollution Bulletin 67: 26-35.

[14] GARMENDIA, M., FDEZ-ORTIZ DE VALLEJUELO, S., LIÑERO, O., GREDILlA, A., ARANA, G., SOTO, M., DE DIEGO, A. 2019. «Long term monitoring of metal pollution in sediments as a tool to investigate the effects of engineering works in estuaries. A case study, the Nerbioi-Ibaizabal estuary (Bilbao, Basque Country)». 145: 555-563. 
[15] ORTIZ-ZARRAGOITIA, M., DIAZ DE CERIO, O., ROJO-BARTOLOMÉ, I., BIZARRO, C., CAJARAVILLE, M.P., CANCIO, I. 2014. «Mugilid fish are sentinels of exposure to endocrine disrupting compounds in coastal and estuarine waters». Marine Drugs 12: 4756-4782.

[16] HURST, D., BØRRESEN, T., ALMESJÖ, L., DE RAEDEMAECKER, F., BERGSETH, S. 2016. «Marine biotechnology strategic research and innovation roadmap: Insights to the future direction of European marine biotechnology». Marine Biotechnology ERA-NET: Oostende. 64. or.

[17] OECD. 2016. «The Ocean Economy in 2030». OECD Publishing, Paris. http://dx.doi.org/10.1787/9789264251724-en.

[18] www.embrc.eu. 2020ko urria. 